\title{
Bioenergetics of small pelagic fishes in upwelling systems: relationship between fish condition, coastal ecosystem dynamics and fisheries
}

\author{
Rui Rosa ${ }^{1, *}$, Liliana Gonzalez ${ }^{2}$, Bernardo R. Broitman ${ }^{3,4}$, Susana Garrido ${ }^{1}$, \\ A. Miguel P. Santos ${ }^{5}$, Maria L. Nunes ${ }^{5}$ \\ ${ }^{1}$ Laboratório Marítimo da Guia, Centro de Oceanografia, Faculdade de Ciências da Universidade de Lisboa, \\ Av. Nossa Senhora do Cabo, 939, 2750-374 Cascais, Portugal \\ ${ }^{2}$ Department of Computer Science and Statistics, University of Rhode Island, 9 Greenhouse Road, Kingston, \\ Rhode Island 02881, USA \\ ${ }^{3}$ Centro de Estudios Avanzados en Zonas Aridas (CEAZA), Facultad de Ciencias del Mar, Universidad Catolica del Norte, \\ Larrondo 1281, Coquimbo, Chile \\ ${ }^{4}$ Center for Advanced Studies in Ecology and Biodiversity (CASEB), Pontificia Universidad Catolica de Chile, Alameda 340, \\ Santiago, Chile \\ ${ }^{5}$ Instituto Nacional de Recursos Biológicos (INRB/L-IPIMAR), Av. Brasília, 1449-006 Lisbon, Portugal
}

\begin{abstract}
Coastal upwelling ecosystems provide the bulk of the world's fishery yields, but the biochemical ecology of the species that make up these fisheries has, surprisingly, been ignored. Biochemical indicators can provide a mechanistic, ecosystem-based link between population and ecosystem dynamics. Here we investigated long-term, inter-annual changes in the proximate composition and energetic condition of European sardine Sardina pilchardus and its relationship with oceanographic conditions in the Western Iberian Upwelling Ecosystem. Energy density (ED) ranged between 4.0 and $14.2 \mathrm{~kJ} \mathrm{~g}^{-1}$, and the seasonal cycle largely determined temporal variability, explaining $>80 \%$ of the observed variation. ED variations were also closely linked with water (total $\mathrm{R}^{2}=$ $99.0 \%$ in whole body; total $\mathrm{R}^{2}=95.0 \%$ in muscle) and lipid dynamics (total $\mathrm{R}^{2}=99.6 \%$ in whole body; total $\mathrm{R}^{2}=92.5 \%$ in muscle). After adjusting for seasonality (rED) and restricting the temporal analysis to the end of the feeding period (August to October), spring/early-summer oceanographic conditions explained $67 \%$ of the late-summer energetic peak. Interestingly, the sardine rED peak in year ( $t$ ) explained $>54.4 \%$ of the variation in the annual catches of year $(t+1)$, indicating that adult energetic condition during spawning is partially translated into the fishery through parental effects in recruitment strength. Our results support earlier findings indicating that sardine population dynamics seem to be controlled by bottom-up effects, but the linkages between population dynamics and patterns in environmental variability via physiological condition seem to have previously been overlooked. We also provide empirical evidence that biochemical assessments during critical periods of the life-cycle of fish are essential in understanding the population dynamics of coastal upwelling ecosystems and in developing a more solid basis for stock management and conservation.
\end{abstract}

KEY WORDS: Sardina pilchardus - Sardines - Proximate composition · Energy density · Western Iberian Upwelling Ecosystem

Resale or republication not permitted without written consent of the publisher

\section{INTRODUCTION}

Many of the highly productive mid-latitude marine ecosystems, particularly coastal upwelling regions, appear to have a 'wasp-waist' food web, whereby the bottom and top of the food chain have high species diversity, while the intermediate trophic levels are occupied by only a few small planktotrophic fish species (Cury et al. 2000). Among these species are sardines, epipelagic fishes that form highly dense neritic 
shoals and play an important role in the food chain and in the ocean's ecology. They serve as a major prey item for other fish, birds and marine mammals and constitute the major target of pelagic fisheries around the world (Beckley \& van der Lingen 1999). Over the last decades, fisheries of small pelagics have experienced dramatic changes in yields and alternating dominance of species (sardine vs. anchovy) around the world (Lluch-Belda et al. 1989). In the Pacific Ocean, these biological regime shifts seem to be associated with multidecadal fluctuations in sea surface temperature, equatorial currents and atmospheric pressure systems (Chavez et al. 2003).

Evidence for the widespread effects of climate variability on fish populations has accumulated in recent years (Attrill \& Power 2002, Edwards \& Richardson 2004) and, though top-down (consumer-driven) removal of fish biomass can have a strong regulatory effect (e.g. Worm \& Myers 2003, Bailey et al. 2006), mid-latitude coastal fisheries appear to be controlled by phytoplankton production (Ware \& Thomson 2005, Frank et al. 2006). Yet, the marked variability in the condition of these exploited fish populations appears to be fuelled by current management practices based on abundance, biomass, or landings (Hsieh et al. 2006), but which ignore climate regime shifts and oceanographic variability (Chavez et al. 2003), food supply to adult fishes (Shulman \& Love 1999, Shulman et al. 2005) and their energy condition (Dutil \& Lambert 2000).

Although biochemical approaches have commonly been used in studies of boreal and polar marine trophic chains (e.g. see review in Dalsgaard et al. 2003), the biochemical ecology of marine food webs from low-latitude temperate zones, where the major pelagic fisheries and upwelling systems are located, has surprisingly been overlooked, and related studies are scarce (Schülein et al. 1995, Paiting et al. 1998). In fact, biochemical indicators can provide major insights into the mechanisms controlling the abundance of small pelagic fishes, since they integrate the impacts of environmental forcing on feeding and are directly linked to fitness, thus offering a powerful complement to traditional indicators (e.g. condition factor).

Here we investigated a more than one decade relationship between the nutritional condition of the European sardine Sardina pilchardus and factors of environmental forcing (namely sea surface temperature and Ekman transport) along the western coast of Portugal. Concomitantly, we investigated a potential relationship between inter-annual variations in sardine bioenergetics (based on proximate composition analyses) and reproductive success (recruitment) and catches. The western coastal area of Portugal is situated in the Western Iberian Upwelling Ecosystem
(WIUE), which comprises the northern limit of the Canary Current Upwelling System (1 of the 4 major eastern boundary currents of the world). The main feature of the region is the occurrence of coastal upwelling during spring and summer in response to the intensification of northerly winds (Fiúza et al. 1982). During autumn and winter, southerly and westerly winds prevail, which along with the interaction of a meridional density gradient on the shelf and slope, cause a poleward flow of warm, salty water that constitutes the Iberian Poleward Current (IPC; Relvas et al. 2007). Yet, an increase in the frequency of equatorward winds and upwelling events during winter (Borges et al. 2003) and a steadily weakening of these winds in the main upwelling season (April to September) have also recently been demonstrated (Lemos \& Pires 2004).

\section{MATERIALS AND METHODS}

Sampling. The present study was performed over a period of $12 \mathrm{yr}$, beginning in January 1984 and concluding in July 1995. Monthly samples (with few gaps) consisting of 2 groups of 6 to 12 adult sardines Sardina pilchardus were taken from a commercial purse seine vessel's catches off the western Portuguese coast, at the fishing port of Peniche (Fig. 1). Since this study was conducted under the framework of a national biotechnological programme that began in 1982 for the 'upgrading of small pelagic fish caught off the Portuguese coast', the size and gender of the specimens analysed were not available. Thus, the bioenergetic models were restricted to relations with the proximate constituents, i.e. without taking fish mass or condition factors into consideration. Nonetheless, acknowledging some of the data-set limitations, the usefulness of long-term data (e.g. oil:meal ratios), collected for industrial/biotechnological purposes, in reconstructing the historical variation in reproductive potential is indisputable (Schülein et al. 1995, Paiting et al. 1998, Marshall et al. 1999). Moreover, although size may influence the chemical characteristics of sardines (Caponio et al. 2004), other studies with small pelagic fish species have revealed no relationship between size (or age) and proximate composition (e.g. Van Pelt et al. 1997, Foy \& Paul 1999, Payne et al. 1999, Eder \& Lewis 2005). Our most recent findings also show that gender has no effect on lipid dynamics (specifically on total fatty acid accumulation) in adult sardines (Garrido et al. 2008b). During the sampling period, larger sized specimens were always chosen from the monthly catches (M. Pires pers. comm.) and, thus, the 2 monthly groups analysed should adequately characterize the nutritional condition of the non-juvenile sardine popu- 


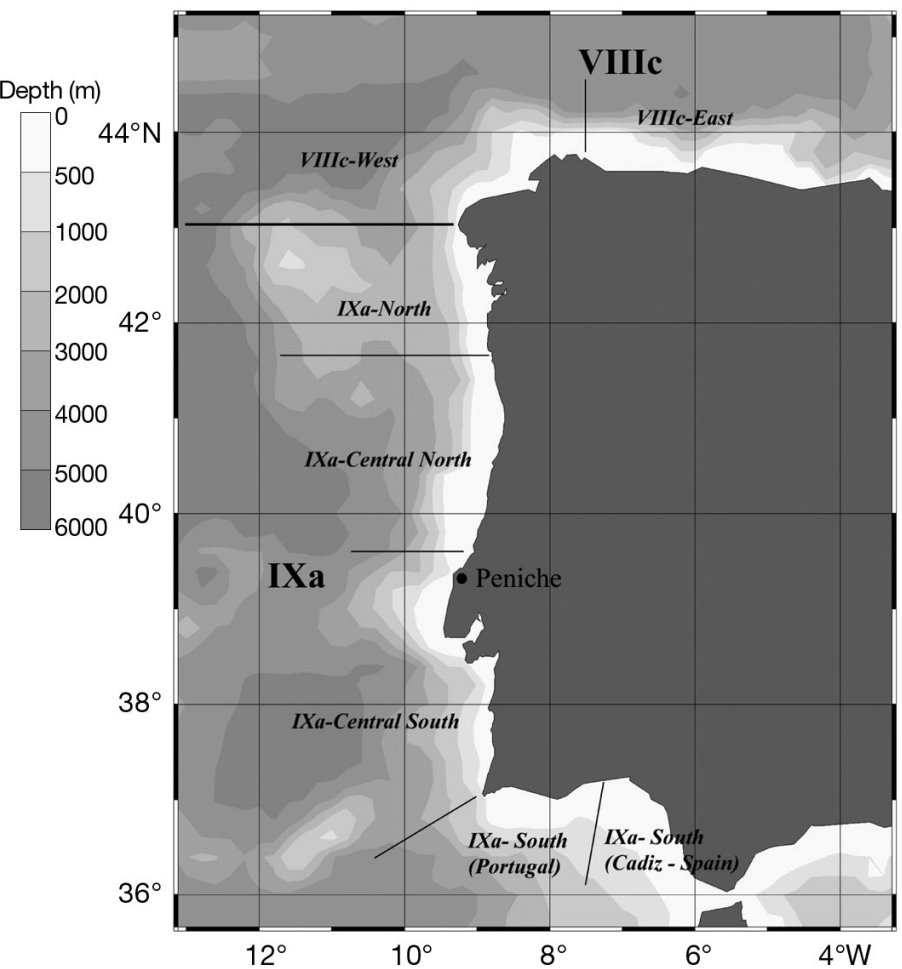

Fig. 1. Sampling location (Peniche) on Portuguese western coast. Subdivisions used by the International Council for the Exploration of the Sea for the Atlanto-Iberian areas are also presented

lation off the western Portuguese coast (sexual maturity occurs mostly between 11 and $17 \mathrm{~cm}$ of total length; Silva et al. 2006). To perform biochemical analyses in the muscle, all specimens of 1 group were beheaded and gutted, the bones and skin removed, and the muscle tissues were then pooled and homogenized twice in a common meat grinder. The entire bodies of the specimens in the second group were homogenized. The 2 group samples (designated as muscle and whole body) were stored at $-20^{\circ} \mathrm{C}$ until the biochemical analyses were done (in duplicate for each group every month).

Biochemical analyses. Water, protein, lipid and ash contents were determined according to procedures by the Association of Official Analytical Chemistry (AOAC 1984, 1990). Moisture content was determined by constant-weight drying in an oven at $100^{\circ} \mathrm{C}$. Protein levels were ascertained by a modified Kjeldahl method, using the value 6.25 as a conversion factor for total nitrogen content to protein. Fat content was evaluated using the Soxhlet extraction method with ethyl ether, and ash content was determined by incinerating in a muffle furnace at $550^{\circ} \mathrm{C}$ to constant weight. Since carbohydrate content is generally low in fish and its contribution to the energetic value is negligible (Payne et al. 1999, Anthony et al. 2000), energy density was estimated by converting proximate constituents based on assumed energy equivalents of $5.65 \mathrm{kcal} \mathrm{g}^{-1}$ for proteins and $9.5 \mathrm{kcal} \mathrm{g}^{-1}$ for lipids (Winberg 1971). All biochemical values were expressed as means \pm SD.

Environmental data. Monthly values of sea surface temperature (SST) and wind over a $1^{\circ} \times 1^{\circ}$ cell off Peniche $\left(39^{\circ} \mathrm{N}, 10^{\circ} \mathrm{W}\right)$, from 1984 to 1995 , were provided by the International Comprehensive Ocean Atmosphere Data Set (COADS) (http://icoads.noaa. gov/products.html) (Woodruff et al. 1998). The offshore Ekman transport $\left(Q_{\mathrm{x}}\right)$, caused by the northern component of the wind stress vector, was computed following Bakun's (1973) formulae:

$$
\begin{aligned}
Q_{\mathrm{x}} & =-\frac{\tau_{y}}{\rho_{\mathrm{sw}} f} 1000 \\
& =-\frac{\rho_{\mathrm{a}} C_{\mathrm{D}}|v| V}{\rho_{\mathrm{sw}} f} 1000\left(\mathrm{~m}^{3} \mathrm{~s}^{-1} \mathrm{~km}^{-1}\right)
\end{aligned}
$$

where $\rho_{\mathrm{a}}$ is the density of air $\left(1.22 \mathrm{~kg} \mathrm{~m}^{-3}\right), C_{\mathrm{D}}$ is a dimensionless drag coefficient $\left(1.3 \times 10^{-3}\right), \rho_{\mathrm{sw}}$ is the density of seawater $\left(\sim 1025 \mathrm{~kg} \mathrm{~m}^{-3}\right), V$ is the monthly average wind vector with magnitude $|v|$ and $f$ is the Coriolis parameter $\left(9.175 \times 10^{-5} \mathrm{~s}^{-1}\right.$ for Peniche $)$. The term $f$ was calculated as:

$$
f=2 \omega \sin \left(f_{i}\right)
$$

where $\omega$ is the angular velocity of the earth $\left(7.29 \times 10^{-5}\right.$ s) and $f_{i}$ is the latitudinal position at the place $i$. Positive values of $Q_{\mathrm{x}}$ indicate upwelling-favourable offshore Ekman transport along the western coast.

Recruitment and landings data. Recruitment (age-0 group; estimated by virtual population analysis) and commercial catch time series data were taken from a publication of the ICES (International Council for the Exploration of the Sea) Working Group on the Assessment of Mackerel, Horse Mackerel, Sardine and Anchovy (ICES 2005). It is worth noting that the composition of the commercial catch-at-age of sardines in the study area (western Portugal) shows that juveniles are available to the fishery and, therefore, the yield variability of commercial catches should represent recruitment variability (Borges et al. 2003).

Statistical analyses. Statistical analysis of the data was carried out with SAS (v. 9.2). Data analyzed were monthly (equally spaced), collected over a period of 12 yr (from January 1984 to July 1995), for a total number of 139 mo. The body biochemical variables had 15 missing observations, mainly in 1986 and 1987 (10 out of 15), and the muscle biochemical variables had 11 missing observations, mainly in 1984 (beginning of sampling period) and 1986 (8 out of 11).

Preliminary examination of the data involved the use of techniques such as correlation analysis and regression analysis. To assess seasonality in each of the vari- 
ables, indicator variables were created for each of the months and a multiple regression analysis was used, in which the dependent variable was a biochemical variable (energy, water, lipids, ash and proteins) and the independent variables were 11 of the 12 indicator variables (1 month was used as the reference month). Time dependency was not accounted for in this part of the analysis, but it was taken into consideration in subsequent analyses; hence, autoregressive (AR) procedures were used. Generalizations of the DurbinWatson test were used to test for the presence of higher order autoregressive components.

In the context of the present paper, a simple linear regression model with first-order autoregressive errors $[\mathrm{AR}(1)]$ can be defined as:

$$
\begin{gathered}
y_{t}=\beta_{0}+\beta_{1} x_{t}+\varepsilon_{t} \\
\varepsilon_{t}=\rho \varepsilon_{t-1}+a_{t}
\end{gathered}
$$

where $y_{t}$ and $x_{t}$ are the $t$ th observations of the response (energy density for body or for muscle) and regression variables (i.e. water, lipids, ash, or protein), respectively, at time $t_{i} \varepsilon_{t}$ is the error term in the model at time $t, a_{t}$ is an $\operatorname{NID}\left(0, \sigma_{a}^{2}\right)$ random variable, and $\rho$ is the autocorrelation parameter. This model can be easily extended to a multiple regression model with $p$ independent variables and an autoregressive error of order $k$, $[\mathrm{AR}(k)]$, by adding additional terms to the model given above. The AUTOREG procedure in SAS was used when autocorrelation in the residuals was present. In cases where there was no time dependency in the residuals, standard multiple regression analysis was used. The goodness-of-fit statistics reported are total $\mathrm{R}^{2}$ such that:

$$
\text { Total } \mathrm{R}^{2}=1-(\mathrm{SSE} / \mathrm{SSC})
$$

where SSC is defined as the corrected sum of squares of the total response variable and SSE is the final error sum of squares, and Akaike's information criterion (AIC) such that:

$$
\mathrm{AIC}=-2 \ln (L)+2 k
$$

where $L$ is the value of the likelihood function evaluated at the parameter estimates and $k$ is the number of estimated parameters. Restricted maximum likelihood was used to estimate model parameters since observations were missing in the data.

Moreover, in order to seasonally adjust each one of the time series, an adaptation of the X11 Seasonal Adjustment Program (developed by the US Bureau of the Census) was used. The X11 procedure in SAS incorporates sliding spans analysis, and it requires that the series be complete. To this end, estimation using regression was used to replace missing values in the data. That is, the variable with the missing observations was treated as the dependent variable, while the variable that correlated to the highest degree with the dependent variable was used as the independent variable. If, after this first step, missing observations were still evident in the dependent variable, the strong seasonality present in the series was taken advantage of and was used for prediction purposes, thus completing the gaps in the data. This process is sometimes referred to as regression mean imputation. It is important to note that because correlation with other series and seasonality within each series was part of the estimation of missing values, the monthly/seasonal fluctuations were captured quite well by the process.

The X11 procedure allows additive and multiplicative adjustments, where an additive model is defined as:

$$
Y_{t}=S_{t}+C_{t}+I_{t}
$$

Here, $Y_{t}$ is the original series at time $t, S_{t}$ is the seasonal component at time $t$, defined as the intra-year variation that is repeated from year to year, $C_{t}$ is the trend cycle component at time $t$ that includes variation due to the long-term trend and other long-term cyclical factors and $I_{t}$ is the irregular component or residual variation at time $t$. To seasonally adjust a series in an additive model implies subtracting the seasonal factor $\left(S_{t}\right)$ from the original series $\left(Y_{t}\right)$, and consists of only the trend cycle and the irregular component.

\section{RESULTS}

\section{Temporal changes in proximate composition}

Time series of monthly variation in the biochemical composition of European sardine Sardina pilchardus are shown in Fig. 2. Water content ranged between 54.6 (August 1991) and $79.1 \%$ of wet weight (WW) (March 1991) in the whole body and between 59.8 (October 1988) and 80.6\% WW (February 1991) in the muscle. An inverse scenario was observed for the lipid

Table 1. Sardina pilchardus. Correlation analyses to assess the linear association between the proximal chemical constituents in the whole body of European sardines. * significant linear associations between the corresponding variables at the $1 \%$ level of significance; ns: non-significant linear associations. Data series used in this analysis contain missing values

\begin{tabular}{|lcccc|}
\hline & Water & Lipids & Ash & Proteins \\
\hline Water & 1.00 & & & \\
Lipids & $-0.99^{*}$ & 1.00 & & \\
Ash & $0.52^{*}$ & $-0.54^{*}$ & 1.00 & \\
Proteins & $0.40^{*}$ & $-0.49^{*}$ & $0.16 \mathrm{~ns}$ & 1.00 \\
\hline
\end{tabular}



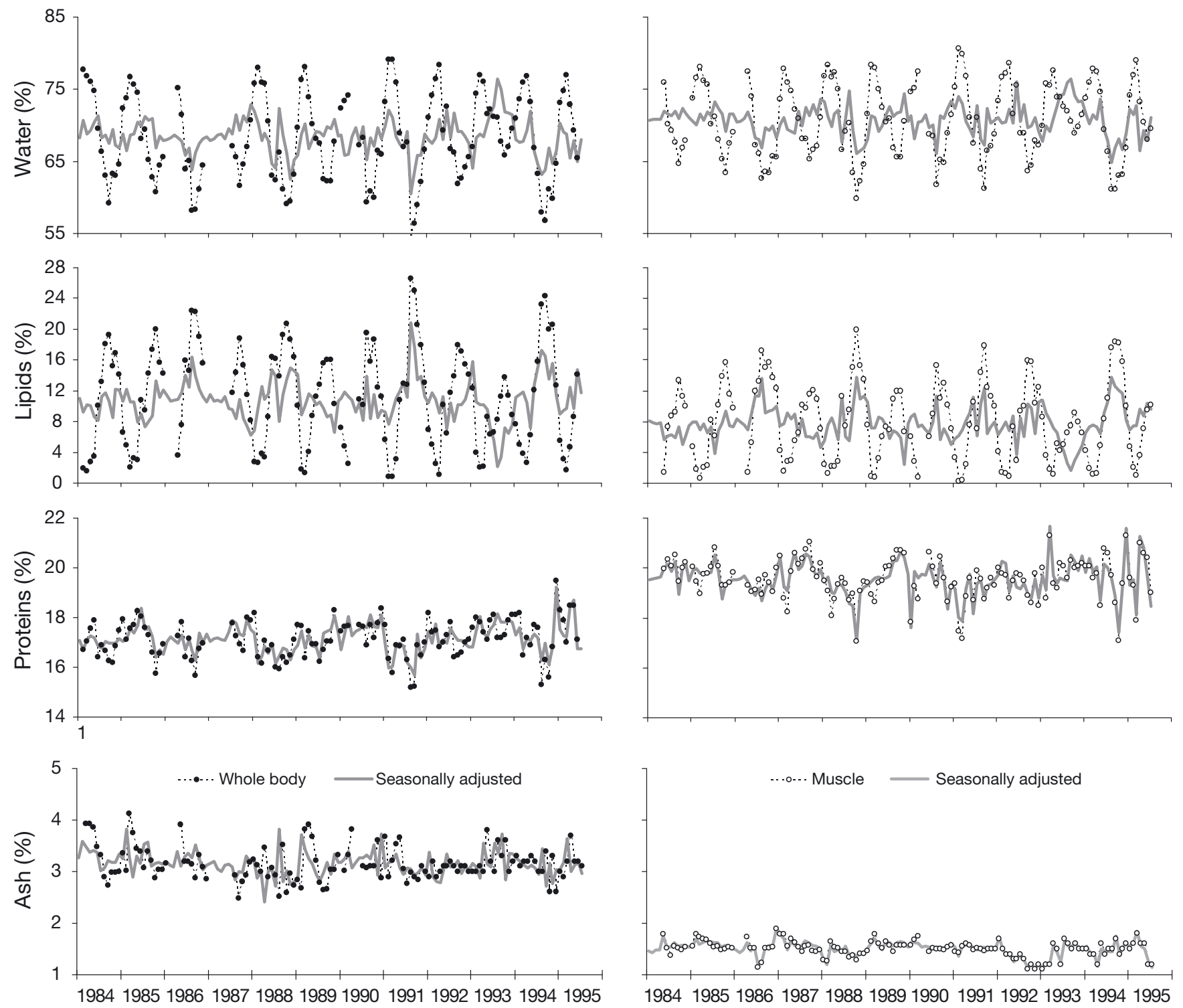

Fig. 2. Sardina pilchardus. Long-term temporal variations (1984 to 1995) in the water, lipid, protein, and ash contents (\% wet weight of body and muscle mass) of European sardine. Seasonally adjusted time series are represented by the thick grey line

content (Fig. 2), which varied between 0.8 (March 1991) and $26.6 \%$ WW (August 1991) for the whole body and between 0.3 (March 1991) and 19.9\% WW (October 1988) in the muscle. A significant negative correlation was attained between these 2 biochemical constituents $(\mathrm{p}<0.0001)$ (Table 1$)$. Both variables showed a marked seasonal variability that explained a large proportion (around $80 \%, \mathrm{p}<0.0001$ ) of the variation in each time series (Table 2). The data used in these analyses contained missing values. It is noteworthy that the results provided in Tables $1 \& 2$ assume independence in the data (i.e. the results do not account for the time dependency in the data).
Significant temporal changes in the protein content were also observed (Fig. 2). The lowest levels were attained in August 1991 (15.2\% WW), and the highest, in December 1994 (19.5\% WW) in the whole body. While positively correlated with water content, proteins were negatively associated with lipid levels (Table 1), i.e. contrary to the lipid trend, the highest protein levels were observed in winter periods, while the lowest were attained in the summer. The ash content varied significantly between 2.5 (August 1987) and $4.1 \%$ WW (February 1985) for the whole body and between 1.1 (September 1992) and 1.9\% WW (December 1986) in the muscle (Fig. 2). 
Table 2. Sardina pilchardus. Assessment of seasonality in energy density and biochemical constituent contents in the whole body and muscle of European sardines, performed using regression analysis, with 11 dummy variables representing the 12 mo of the year $(1 \mathrm{mo}$ is used as a reference class). $\mathrm{R}^{2}$ : percent of total variability in each of the variables explain by seasonality alone (note that no attempt was made to account for time dependency in the data since the interest laid in assessing only the seasonality effect). Data series used in the analyses contain missing observations

\begin{tabular}{|lrrr|}
\hline Variable & $\mathrm{R}^{2}(\%)$ & $F$ & $\mathrm{p}$ \\
\hline Whole body & & & \\
Energy & 81.23 & 44.07 & $<0.0001$ \\
Water & 81.55 & 45.00 & $<0.0001$ \\
Lipids & 80.06 & 40.87 & $<0.0001$ \\
Protein & 32.68 & 4.94 & $<0.0001$ \\
Ash & 33.81 & 5.20 & $<0.0001$ \\
Muscle & & & \\
Energy & 80.15 & 42.58 & $<0.0001$ \\
Water & 80.69 & 44.05 & $<0.0001$ \\
Lipids & 77.78 & 36.92 & $<0.0001$ \\
Protein & 16.71 & 2.12 & 0.0243 \\
Ash & 9.18 & 1.07 & 0.3948 \\
\hline
\end{tabular}

\section{Energy density and empirical bioenergetic models}

Energy density (ED, $\mathrm{kJ} \mathrm{g}^{-1}$ ) temporal dynamics (Fig. 3) was closely linked with lipid content (Model 2 [M2] - for whole body, total $\mathrm{R}^{2}=99.60 \%$; for muscle, total $\mathrm{R}^{2}=92.50 \%$; Table 3 ) and much of the ED variation in the whole body and muscle was explained by seasonality (>80\%; Table 2). ED ranged between 4.0 (March 1991) and $14.2 \mathrm{~kJ} \mathrm{~g}^{-1} \mathrm{WW}$ (August 1991) in the whole body and between 4.1 (March 1991) and $11.9 \mathrm{~kJ}$ $\mathrm{g}^{-1}$ WW (October 1988) in the muscle. A significant negative relationship between ED and water content was obtained (Model 1 [M1] - for whole body, total $\mathrm{R}^{2}=98.98 \%$; for muscle, total $\mathrm{R}^{2}=94.96 \%$; Table 3 ). The sardine energetic peak was always attained at the end of summer and beginning of autumn (August to October), and it was more pronounced in the years 1986, 1991 and 1994, with average values of 12.3, 13.3 and $13.2 \mathrm{~kJ} \mathrm{~g}^{-1}$ wet body mass, respectively (Fig. 3). The lower energetic peak was observed in 1993 with $8.47 \mathrm{~kJ} \mathrm{~g}^{-1}$ wet body mass. The empirical models of ED based on protein and ash contents for adult sardines are also shown in Table 3 (Models M3 \& M4).

\section{Energy density and environmental conditions}

Deviations from the seasonal cycle in ED are dynamic indicators of the total energy budget available for the sardines to reproduce and are driven by past feeding conditions, which are determined by environmental forcing. The linkage between sardine energetic condition and environmental variability in the Western Iberian Upwelling Ecosystem was examined by comparing the entire time series of adult sardine ED (whole body) with SST and offshore Ekman transport $\left(Q_{\mathrm{x}}\right)$ (Fig. 3). When we examined the temporal structure of the association between seasonally adjusted energy density (rED; thick grey lines in Fig. 3) and the given environmental variables, we found significant lagged associations with SST and $Q_{\mathrm{x}}$ (lags of 2 and 3 mo; see Appendix, Table A1). A multiple regression

Table 3. Sardina pilchardus. Empirical models (M1 to M4) of energy density (ED, $\mathrm{kJ} \mathrm{g}^{-1}$ wet weight) for adult European sardines based on the proximate constituents of the whole body and muscle (\% wet weight). Both estimates contain the correlation structures in the data taken into consideration. Akaike information criteria (AIC) are given, with smaller values indicating a better fit. Restricted maximum-likelihood was used to estimate the parameters in the models, since they were fitted to series containing missing values. Statistical significance at the ${ }^{*} 5 \%$; ${ }^{* *} 1 \%$ level of significance, AR(1): first-order autogressive models; SE: standard error, in parentheses

\begin{tabular}{|c|c|c|c|c|c|c|c|c|c|c|c|}
\hline \multirow{2}{*}{$\begin{array}{l}\text { Bioenergetic } \\
\text { model }\end{array}$} & \multirow{2}{*}{ Variable } & \multicolumn{5}{|c|}{ Whole body } & \multicolumn{5}{|c|}{ _Muscle } \\
\hline & & Estimate (SE) & $t$ & $\mathrm{p}$ & Total $\mathrm{R}^{2}$ & \%) AIC & Estimate (SE) & $t$ & $\mathrm{p} \quad \mathrm{T}$ & Total R $\left.\mathrm{R}^{2} \%\right)$ & ) $\mathrm{AIC}$ \\
\hline \multirow[t]{3}{*}{ M1 } & Intercept & $36.24(0.31)$ & $118.03^{* *}$ & $<0.0001$ & 98.98 & 12.93 & $40.68(0.94)$ & $43.42^{* *}$ & $<0.0001$ & 194.96 & 202.88 \\
\hline & Water (\%) & $-0.41(0.00)$ & $-91.07^{* *}$ & $<0.0001$ & & & $-0.46(0.01)$ & $-34.49^{* *}$ & $<0.0001$ & & \\
\hline & $\mathrm{AR}(1)$ & $0.22(0.10)$ & $2.34^{*}$ & 0.0209 & & & $0.37(0.09)$ & $4.17^{* *}$ & $<0.0001$ & & \\
\hline \multirow[t]{3}{*}{ M2 } & Intercept & $4.20(0.04)$ & $109.65^{* *}$ & $<0.0001$ & 99.60 & -101.32 & $4.87(0.15)$ & $32.42^{* *}$ & $<0.0001$ & 192.50 & 250.20 \\
\hline & Lipids (\%) & $0.38(0.00)$ & $131.21^{* *}$ & $<0.0001$ & & & $0.45(0.02)$ & $29.16^{* *}$ & $<0.0001$ & & \\
\hline & $\mathrm{AR}(1)$ & $0.34(0.09)$ & $3.93^{* *}$ & 0.0001 & & & $0.28(0.09)$ & $3.07^{* *}$ & 0.0027 & & \\
\hline \multirow[t]{3}{*}{ M3 } & Intercept & $16.42(2.69)$ & $6.10^{* *}$ & $<0.0001$ & 87.29 & 349.15 & $7.62(2.51)$ & $3.04^{* *}$ & 0.003 & 86.02 & 348.32 \\
\hline & Proteins (\%) & $-0.41(0.15)$ & $-2.75^{* *}$ & 0.007 & & & $0.07(0.13)$ & $0.57^{* *}$ & 0.5726 & & \\
\hline & $\mathrm{AR}(1)$ & $0.46(0.09)$ & $5.39^{* *}$ & $<0.0001$ & & & $0.54(0.08)$ & $6.57^{* *}$ & $<0.0001$ & & \\
\hline \multirow[t]{3}{*}{ M4 } & Intercept & $11.61(1.06)$ & $10.96^{* *}$ & $<0.0001$ & 87.26 & 349.66 & $9.25(1.15)$ & $8.01^{* *}$ & $<0.0001$ & 185.97 & 348.61 \\
\hline & Ash (\%) & $-0.79(0.31)$ & $-2.53^{*}$ & 0.0128 & & & $-0.15(0.73)$ & -0.21 & 0.8319 & & \\
\hline & $\mathrm{AR}(1)$ & $0.50(0.08)$ & $5.91^{* *}$ & $<0.0001$ & & & $0.52(0.08)$ & $6.29^{* *}$ & $<0.0001$ & & \\
\hline
\end{tabular}


model that included lag effects of the second and third order for SST and of the third order for $Q_{\mathrm{x}}$, as well as adjusted for the time dependency in the data, explained about $36 \%$ of the total variation left in the rED, the seasonally adjusted series (Model 1, Table 4). Lagged SST was negatively associated with $\mathrm{rED}$, and
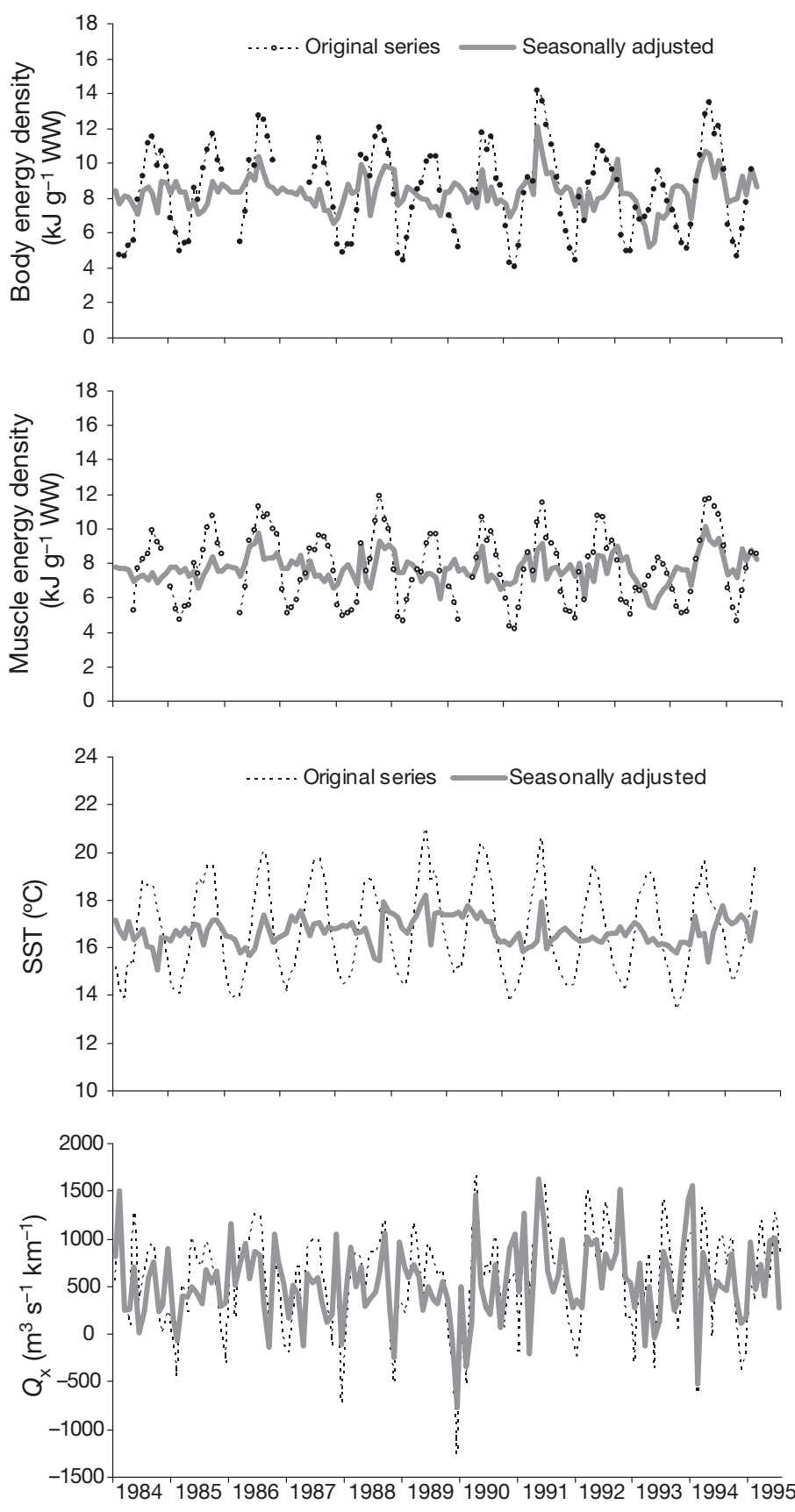

Fig. 3. Sardina pilchardus. Long-term temporal variations (1984 to 1995) in the energy density ( $\mathrm{kJ} \mathrm{g}^{-1}$ wet weight) of the whole body and muscle of European sardine, and in the sea surface temperature $\left(\mathrm{SST},{ }^{\circ} \mathrm{C}\right)$ and Ekman transport $\left(Q_{\mathrm{x}}, \mathrm{m}^{3}\right.$ $\mathrm{s}^{-1} \mathrm{~km}^{-1}$, positive values mean offshore transport). Seasonally adjusted time series are represented by the thick grey line lagged $Q_{\mathrm{X}}$ was positively associated with sardine condition (Fig. 4). The combination of environmental conditions that triggered positive anomalies in sardine energy density - colder ocean temperatures associated with positive Ekman transport values-correspond to upwelling conditions favourable for the spring/early summer phyto- and zooplankton blooms. These environmental conditions are critical for adult fish feeding in order to maximize their late summer energy peak before starting into the prolonged winter spawning season. Therefore, restricting rED analysis to the end of the main feeding period (between August and October), we found that the spring/early summer environmental variability (best model included the 3 mo lagged SST and the 2 and 3 mo lagged $Q_{\mathrm{x}}$ ) explained $67 \%$ of the late summer peak of rED (Model 2 , Table 4). The results for testing for individual variables and lags are shown in Appendix Table A1 - with full data set; and Table A2-end of the main feeding period, i.e. summer peak.

\section{Energy density, recruitment and landings}

Do better feeding conditions and sardine energetic condition translate into enhanced reproductive success and fish production? No significant association between sardine higher $\mathrm{rED}$ and recruitment $(t+1)$ was attained (total $\mathrm{R}^{2}=24.53 \%, \mathrm{p}=0.1214$ ) (Table 5). We also examined the association of landings in year $(t+1)$ on the sardine energetic peak condition (rED) in year $(t)$, by aggregating annual landings from the ICES zones corresponding to the western Portuguese coast (ICES subdivisions IXa center-north and IXa centersouth). Adult energetic condition (at the end of the main feeding period) in year $(t)$ explained $>54.4 \%$ of the variation in catches in year $(t+1)$ (Table 5$)$. The time correlation in residuals was strong; hence, it was necessary to account for the time dependency in this part of the analysis.

\section{DISCUSSION}

\section{Biochemical indicators of sardine condition}

The best biochemical predictors for sardine Sardina pilchardus condition were the lipid and water contents, which explained $>98 \%$ of the variance in ED. Both proteins and ash also proved to be good biochemical indicators by explaining around 80 to $85 \%$ of the ED variance. Thus, it was possible to accurately estimate the energetic condition of adult European sardine based on several empirical bioenergetic models (Table 3). Since ED was not modelled as a function of 
size, the validity of the models for juveniles may be reduced, because sardine juveniles may allocate energy differently than adults (Caponio et al. 2004). However, several other studies with small pelagic fish species have revealed no relationship between size (or age) and proximate composition (e.g. capelin-Van Pelt et al. 1997, herring-Foy \& Paul 1999, capelinPayne et al. 1999, mackerel-Eder \& Lewis 2005). The magnitude and direction of the correlation between ED and size or age differed greatly among studies and

Table 4. Sardina pilchardus. Models assessing the importance of sea-surface temperature (SST) and scaled offshore Ekman transport $\left(Q_{\mathrm{X}} / 100\right)$ in predicting the seasonally adjusted body energy density (rED) for the entire monthly time series (from January 1984 to July 1995, Model 1) and restricted to the end of the main feeding period of European sardines (i.e. summer peak, averaged between August and October, Model 2). Akaike information criteria (AIC) are given, with smaller values indicating a better fit. The variables included in the models were the ones that showed significance in the entries in Table A1 (full data set) and Table A2 (end of feeding period) (in Appendix 1). Statistical significance at the ${ }^{*} 5 \%,{ }^{*} 1 \%$ level of significance; AR(1): first-order autogressive models; SE: standard error, in parentheses

\begin{tabular}{|c|c|c|c|c|c|c|c|c|c|c|}
\hline & \multicolumn{5}{|c|}{ Without autocorrelation } & \multicolumn{5}{|c|}{ - With autocorrelation } \\
\hline & Coefficient (SE) & $t$ & $\mathrm{p} \quad \mathrm{T}$ & Total $\mathrm{R}^{2}(\%)$ & $\mathrm{AIC}$ & Coefficient (SE) & $t$ & $\mathrm{p}$ & Total $\mathrm{R}^{2}(\%)$ & $\mathrm{AIC}$ \\
\hline \multicolumn{11}{|l|}{ Model 1} \\
\hline SST (Lag 2) & $-0.03(0.19)$ & -0.16 & 0.8759 & 13 & 349.62 & $-0.09(0.16)$ & -0.53 & 0.5949 & 36 & 314.91 \\
\hline SST (Lag 3) & $-0.40(0.19)$ & -2.15 & $0.0332^{*}$ & & & $-0.25(0.17)$ & -1.46 & 0.146 & & \\
\hline$Q_{\mathrm{x}}(\operatorname{Lag} 3)$ & $0.05(0.02)$ & 2.31 & $0.0228^{*}$ & & & $0.03(0.02)$ & 1.63 & 0.1068 & & \\
\hline $\mathrm{AR}(1)$ & & & & & & $0.52(0.08)$ & $6.57^{* *}$ & $<0.0001$ & & \\
\hline \multicolumn{11}{|l|}{ Model 2} \\
\hline SST (Lag 3) & $-0.27(0.47)$ & -0.58 & 0.5655 & 32.27 & 113.16 & $-0.07(0.42)$ & -0.17 & 0.8665 & 67.44 & 99.23 \\
\hline$Q_{\mathrm{x}}(\operatorname{Lag} 2)$ & $0.09(0.10)$ & 0.88 & 0.3842 & & & $0.15(0.07)$ & $2.30^{*}$ & 0.0288 & & \\
\hline$Q_{\mathrm{x}}(\operatorname{Lag} 3)$ & $0.18(0.08)$ & $2.19^{*}$ & 0.037 & & & $0.11(0.06)$ & 1.88 & 0.0699 & & \\
\hline $\mathrm{AR}(1)$ & & & & & & $0.73(0.12)$ & $6.10^{* *}$ & $<0.0001$ & & \\
\hline
\end{tabular}
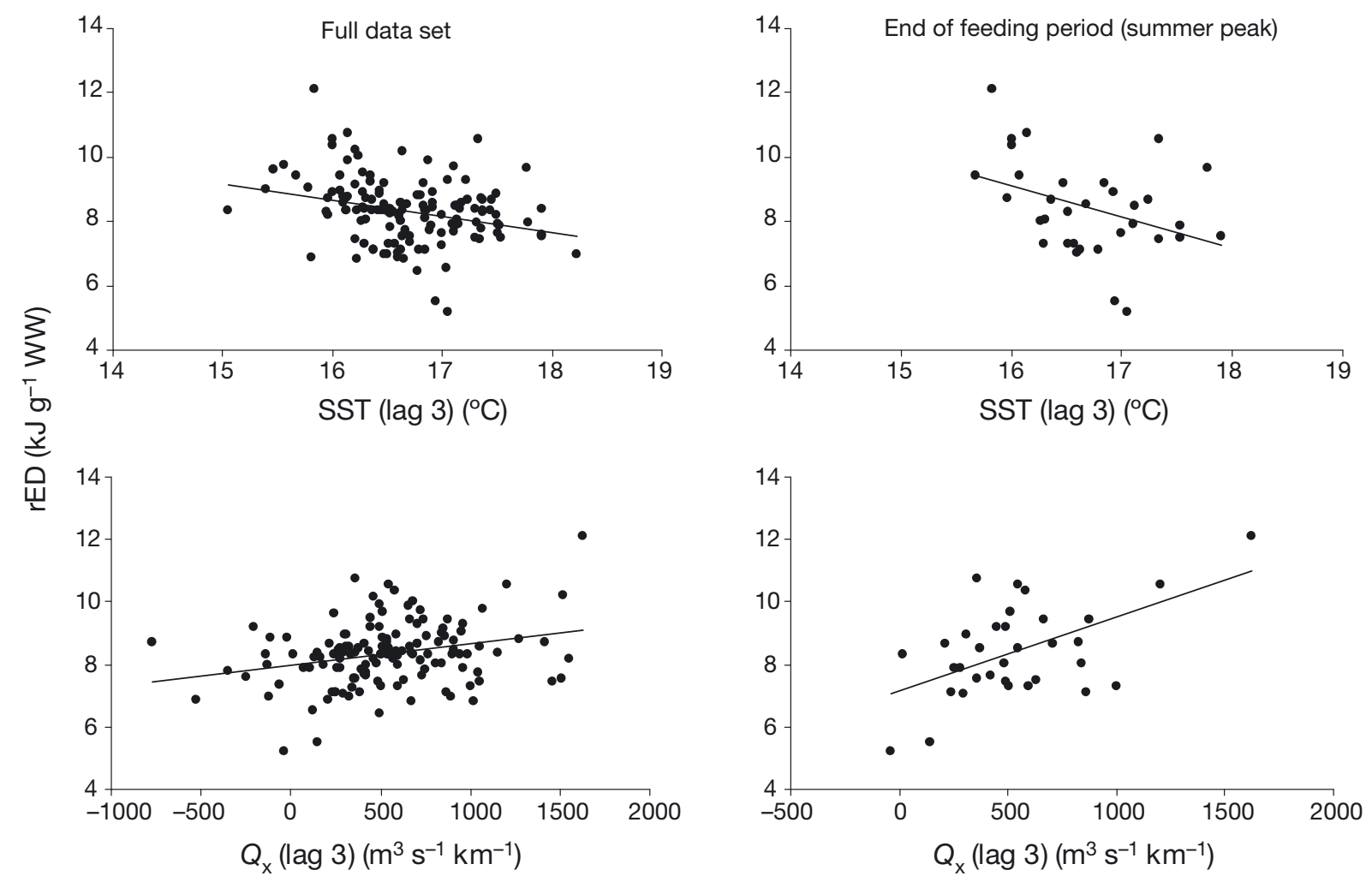

Fig. 4. Sardina pilchardus. Relationships between seasonally adjusted sardine energy (rED, $\mathrm{kJ} \mathrm{g}^{-1}$ wet weight) and earlier oceanographic conditions, namely seasonally adjusted sea surface temperature (SST) and Ekman transport ( $\left.Q_{\mathrm{x}}\right)$ with a 3 mo lag, during the entire studied period (left panels) or restricted to the end of the main feeding period (summer peak; right panels). Since autocorrelation was not taken into account, these statistics are only used for comparative purposes 
Table 5. Sardina pilchardus. Relationships between seasonally adjusted energy density (rED) at the end of the main feeding period of European sardines (between August and October) and sardine recruitment (1000s) in the following year (R0 $(t+1))$ as well as catches $\left(10^{3}\right.$ tons $)$ in the following year $(t+1)$ and $2 \mathrm{yr}$ thereafter $(t+2)$. Time series of catches corresponds to the total across the ICES subdivisions IXa central-north and IXa central-south (western Portuguese coast), while recruitment estimates are relative to the entire Ibero-Atlantic stock. Akaike information criteria (AIC) are given, with smaller values indicating a better fit. Restricted maximum-likelihood was used to estimate the parameters of each of the models (with or without taking autocorrelation into account). Results without autocorrelation assume independence, whereas those with autocorrelation provide information on models that required adjustments for time dependency. Statistical significance at the ${ }^{*} 5 \%$ level of significance; AR(1): first-order autogressive models; SE: standard error, in parentheses

\begin{tabular}{|c|c|c|c|c|c|c|c|c|c|c|}
\hline \multirow{2}{*}{$\begin{array}{l}\text { Dependent } \\
\text { variable }\end{array}$} & \multicolumn{5}{|c|}{ Without autocorrelation -} & \multicolumn{5}{|c|}{-With autocorrelation } \\
\hline & Coefficient (SE) & $t$ & $\mathrm{p}$ & Total $\mathrm{R}^{2}(\%)$ & ) $\mathrm{AIC}$ & Coefficient (SE) & $t$ & $\mathrm{p}$ & Total $\mathrm{R}^{2}(\%)$ & AIC \\
\hline $\mathrm{R} 0(t+1)$ & $\begin{array}{l}1032287 \\
(602933)\end{array}$ & 1.71 & 0.1214 & 24.53 & 357.25 & & & & & \\
\hline $\begin{array}{l}\text { Catch }(t+1) \\
\text { AR(1) }\end{array}$ & $-3.08(1.62)$ & -1.90 & 0.0902 & 28.58 & 75.11 & $\begin{array}{r}-2.78(1.05) \\
0.72(0.25)\end{array}$ & $\begin{array}{r}-2.66^{*} \\
2.85^{*}\end{array}$ & $\begin{array}{l}0.0289 \\
0.0213\end{array}$ & 54.44 & 72.89 \\
\hline Catch $(t+2)$ & $1.54(1.61)$ & 0.95 & 0.3688 & 10.18 & 66.13 & & & & & \\
\hline
\end{tabular}

fish groups, indicating that using a single relationship between ED and size could potentially bias the outcome of bioenergetic models (Madenjian et al. 2000, Trudel et al. 2005).

It has also been assumed that a condition factor (weight/length ${ }^{3}$ ) can be used as an indicator of fish condition; however, it seems that lipids and ED are often poorly correlated with such a condition factor, since it usually only explains $<40 \%$ of the ED variance (Jonas et al. 1996, Sutton et al. 2000, Trudel et al. 2005). The advantage of using biochemical approaches instead of common morpho-physiological indices as indicators of fish condition has been shown in clupeoids (Shulman \& Love 1999). The utilization of lipid reserves can actually result in an increase in body weight due to a consequent increase in the water content, i.e. water replaces lipids while maintaining body shape (Love 1980).

Sardines play an important role in food web dynamics and their high biomasses; the shoaling behaviour and high ED of sardines may explain their importance as prey for numerous marine predators. European sardine condition in summer (ED up to $14.2 \mathrm{~kJ} \mathrm{~g}^{-1} \mathrm{WW}$ ) showed higher ED values than other pelagic demersal prey species (Childress et al. 1990, Van Pelt et al. 1997, Lawson et al. 1998, Payne et al. 1999, Anthony et al. 2000, Tierney et al. 2002, Eder \& Lewis 2005). These prey quality estimates may be crucial inputs to bioenergetic models of predator consumption in the Atlanto-Iberian coastal ecosystem.

\section{Biochemical energetics, feeding ecology and reproduction}

Sardines feed year round and are capable of performing both particle- and filter-feeding depending on prey size (Garrido et al. 2007a). Their omnivorous diet comprises the major plankton groups in the water column, namely crustacean eggs, copepods, decapods, cirripedes, fish eggs, dinoflagellates and diatoms (Garrido et al. 2008a). Contrarily to phytoplankton, which are particularly important during spring and summer, zooplankton are a more perennial dietary component in the WIUE (Garrido et al. 2008a,b). While zooplankton is the major contributor to the proteins of sardines (Bode et al. 2004), fatty acids of herbivorous origin contribute significantly to the lipidic fraction of this fish, particularly off western Iberia, as a result of higher primary productivity related to upwelling events (Garrido et al. $2007 \mathrm{~b}, 2008 \mathrm{a}, \mathrm{b})$.

The seasonal cycle of sardines' metabolic energy depends primarily on the seasonal investment in the spawning season. The accumulation of energy reserves for sardines off western Iberia begins, every year, from energetic exhaustion around March to April (with an average of $5.1 \mathrm{~kJ} \mathrm{~g}^{-1}$ wet body mass) and reaches a peak at the end of September to October (with an average of $11.2 \mathrm{~kJ} \mathrm{~g}^{-1}$ wet body mass), i.e. after the occurrence of the spring and summer planktonic blooms. The decreasing period of adult ED values after September to October reflects primarily the beginning of the protracted spawning season, when a large portion of the energy accumulated is invested in gametogenesis, but also lower food availability and quality (discussed below) during that period. Also, the fact that available energy just prior to spawning reflects the spring/early summer upwelling conditions (Model 2, Table 4; more discussion below) agrees with the evidence that feeding intensity for sardines during these periods is significantly higher than that observed during late summer (Garrido et al. 2008a).

One may argue that the energy allocated to sardine reproduction may also come directly from feeding dur- 
ing the spawning season. However, the lipid content of sardine muscle reserves that has been accumulated during the entire resting stage of reproduction sharply decreases when sardines start to reproduce, suggesting that most of the energy invested in reproduction comes from these reserves, a result that is in accordance with other studies on small pelagic fish (e.g. Hunter \& Leong 1981).

Sardines have a fractional spawning system that depends on the release of multiple egg batches at intervals (Cunha et al. 1992). Being indeterminate spawners, the fecundity of sardines within a given season is not fixed a priori; instead, further batches can be produced in years of abundant food availability during the spawning season (Blaxter \& Hunter 1982). This strategy extends the season to several months and, therefore, may be considered an exploratory reproductive behaviour in response to the variability and unpredictability of habitat conditions in coastal upwelling ecosystems. The spawning season is also characterized by agedependent fecundity (larger individuals spawn over a longer time period and start spawning earlier and finish later than the smaller individuals) (Zwolinski et al. 2001). Because the seasonal cycle is so strong, sardines in February to March are always lean irrespective of the amount of energy they were able to accumulate prior to the spawning season. Sardine ED at the end of the spawning season remained fairly constant over the years and was independent of being preceded by a productive or unproductive spring/early summer. Thus, the amount of energy accumulated by the fish seems to be directly translated in more or less energy available for reproduction, and, therefore, the spawning season may end when the available energy decreases below a certain threshold. In the northern anchovy, two-thirds of the energy required for reproduction during a season was provided by the reserves accumulated prior to the reproductive period (Hunter 1981).

\section{Effect of environmental forcing on sardine bioenergetics}

Sardine-enhanced energetic fitness in some years (namely 1991 and 1994) could not be corroborated with plankton data, but the occurrence of earlier favourable environmental conditions (high $Q_{\mathrm{x}}$ values) suggests increased food availability off the western Portuguese coast in those years. A similar, but opposite, interpretation can be made for 1993, when the lowest ED values were registered (Fig. 3). These assumptions are supported by the strong inter-annual correlation between the upwelling index and shelf production off northwestern Iberia (Joint et al. 2002). Moreover, when we restrict our rED analysis to the end of the feeding period (between August and October), the spring/early summer conditions explained $67 \%$ of the late summer energetic peak (Model 2, Table 4). The differences in upwelling intensity would influence the diatomdominated phytoplankton blooms and the mixing of stratification gradients, which are responsible for the phytoplankton assemblage composition and seasonal succession. Fish conditions benefit more from diatombased food chains (St John \& Lund 1996, Pedersen et al. 1999) than from the more heterotrophic food chains occurring in summer (flagellates and ciliates) and early fall (dinoflagellates) (for more details on phytoplankton succession in upwelling systems see Kudela et al. 2005). Since the last are less efficient in the transfer of energy to higher trophic levels (Cushing 1989, Nagata et al. 1996), sardine conditions would primarily be enhanced by grazing on zooplankton that contain the dietary lipids of diatom origin from spring and early summer blooms. In fact, since some zooplankton groups, namely copepods (one of the major contributors to the sardine's dietary carbon; Garrido et al. 2008a), are known to accumulate large lipid stores (mainly wax esters and triacylglycerols) in the hepatopancreas, digestive tract, ovaries and in oil sacs and droplets (Lee et al. 2006), sardine ED variations may be linked to the seasonal lipid dynamics in these groups of prey. Although less relevant for the overall energetic condition of Sardina pilchardus, muscle proteins also have a zooplankton origin (Bode et al. 2004). Nonetheless, in other small pelagic species, protein is regarded as an essential source of energy to fuel reproduction (Bradford 1993).

Note that the role of diatoms in marine food webs has recently been questioned, in connection with their teratogenic effect on copepods (Miralto et al. 1999, Ianora et al. 2004). The established concept of energy flow from diatoms to fish by means of copepods is presently being debated by questioning the ecological significance of laboratory experiments on diatom toxicity (Jones \& Flynn 2005) and by defending the classical model for a diatom-dominated system based on large-scale field studies (Irigoien et al. 2002). Diatoms may also be an important link between climatic and some ecosystem changes (Irigoien et al. 2000) and may, therefore, be a keystone for the lifehistory success of small pelagic planktotrophic fish such as sardines, the biological features of which are closely linked to the basic characteristics that influence ecosystem productivity.

\section{Sardine bioenergetics, recruitment and landings}

The weak relationship between enhanced rED and recruitment success in the following year $(p>0.05)$ 
(Table 5) seems, at first glance, to support the deterministic role of environmental factors in the survival of early life-history stages, e.g. the coastal upwelling conditions during winter (discussed above). Yet, these recruitment estimates are relative to the entire IberoAtlantic stock (delimited by the French/Spanish border in the north and by the Strait of Gibraltar in the south; ICES Divisions VIIIC and IXa) and are not exclusive to the WIUE, i.e. the recruitment data available have a low spatial resolution. Silva et al. (2006) showed that regional differences in the maturity, age structure and condition factor of sardines are observed; thus, a database that integrates the Cantabrian, western and southern Iberian spawning sites (ICES 2005) is not adequate.

In the WIUE, the main spawning and recruitment areas are located off the NW Portuguese coast, where young fish are mainly caught (Ré et al. 1990, Alvarez \& Alemany 1997, Marques et al. 2003). Interestingly, sardine rED (at the end of the main feeding period) in year ( $t$ ) explained $>54.4 \%$ of the variation in regional catches (ICES subdivisions IXa central-north and IXa central-south) in year $(t+1)$ (Table 5), indicating that adult energetic condition during spawning is partially translated into the fishery through recruitment strength.

Sardine spawners in better physiological condition have higher reproductive outputs (more batches of eggs per season and more viable eggs per batch) than fish in lower condition, which increase the probability of recruitment success and produce a stronger yearclass that, apparently, is influential enough to be reflected in the fisheries of the following year. In fact, the beginning of the sardine spawning season in October (Figueiredo \& Santos 1988, Ré et al. 1990) is known to generate a gradual increase in the new recruits to the fishery during the second semester of the following year (e.g. ICES 1982). As a consequence, the catches in the WIUE are generally higher during the second half of the year in comparison to the first semester, reflecting the influx of new recruits (e.g. ICES 2005). Nonetheless, other factors also potentially determine recruitment strength, namely predation, cannibalism, advection of eggs (and larvae) and the density of the parental stock (Beckley \& van der Lingen 1999, Coetzee et al. 2008).

\section{CONCLUSIONS}

Our results support earlier findings which indicate that sardine population dynamics seem to be controlled by bottom-up effects (Santos et al. 2001, Borges et al. 2003). Although acknowledging the dataset limitations, it was apparent that the variability of sardine
ED related to the environmental forcing during the spring/early summer months is sufficiently important to be reflected in the fisheries. Thus, the condition of spawners, prior to the reproductive season, is a prerequisite to detecting the environmental and ecological effects on recruitment and, therefore, needs to be taken into consideration in stock management. Rapid energy determinations (e.g. indirectly by proximate constituents or directly by calorimetry) offer a low-cost and straightforward tool for fisheries assessments. Besides considerations of variable mortality, the inclusion of ED or other biochemical indicators may provide mechanistic proxies for reproductive investment beyond traditional spawning biomass. Our results provide empirical evidence that energy assessments during critical periods of the fish life-cycle (at the end of the feeding period) are an essential aspect in understanding the population dynamics in small pelagic fishes in coastal upwelling ecosystems and in developing a more solid basis for stock management and conservation.

Acknowledgements. We thank the staff of the Departamento de Inovação Tecnológica e Valorização dos Produtos da Pesca (especially Angelino Martins and Manuel Pires) for their help in the extensive technical components of the present study. B. Seibel and C. Kappel provided discussion and comments on the work. This research was conducted within the framework of a programme financed by the Portuguese Ministry of Agriculture and Fisheries.

\section{LITERATURE CITED}

Alvarez F, Alemany F (1997) Birthdate analysis and its implication to the study of recruitment of the Atlanto-Iberian sardine Sardina pilchardus. Fish Bull 95:187-194

Anthony JA, Roby DD, Turco KR (2000) Lipid content and energy density of forage fishes from the northern Gulf of Alaska. J Exp Mar Biol Ecol 248:53-78

AOAC (Association of Official Analytical Chemistry) (1984) Official methods of analysis. AOAC, Washington, DC

AOAC (Association of Official Analytical Chemistry) (1990) Official methods of analysis. AOAC, Washington, DC

Attrill MJ, Power M (2002) Climatic influence on a marine fish assemblage. Nature 417:275-278

Bailey DM, Ruhl HA, Smith KL (2006) Long-term change in benthopelagic fish abundance in the abyssal northeast Pacific Ocean. Ecology 87:549-555

Bakun A (1973) Coastal upwelling indices, west coast of North America, 1946-71. NOAA Tech Rep 671

> Beckley LE, van der Lingen CD (1999) Biology, fishery and management of sardines (Sardinops sagax) in southern African waters. Mar Freshw Res 50:955-978

Blaxter JHS, Hunter JR (1982) The biology of the clupeoid fishes. Adv Mar Biol 20:1-223

Bode A, Alvarez-Ossorio MT, Carrera P, Lorenzo J (2004) Reconstruction of trophic pathways between plankton and the North Iberian sardine (Sardina pilchardus) using stable isotopes. Sci Mar 68:165-178

Borges MF, Santos AMP, Crato N, Mendes H, Mota B (2003) Sardine regime shifts off Portugal: a time series analysis of 
catches and wind conditions. Sci Mar 67:235-244

Bradford RG (1993) Role of spawning condition in the determination of the reproductive traits of spring- and autumnspawning Atlantic herring from the southern Gulf of St. Lawrence. Can J Zool 71:309-317

Caponio F, Lestingi A, Summo C, Bilancia MT, Laudadio V (2004) Chemical characteristics and lipid fraction quality of sardines (Sardina pilchardus W.): influence of sex and length. J Appl Ichthyology 20:530-535

- Chavez FP, Ryan J, Lluch-Cota SE, Niquen M (2003) From anchovies to sardines and back: multidecadal change in the Pacific Ocean. Science 299:217-221

Childress JJ, Price MH, Favuzzi J, Cowles D (1990) Chemical composition of midwater fishes as a function of depth of occurrence off the Hawaiian Islands: food availability as a selective factor? Mar Biol 105:235-246

Coetzee JC, van der Lingen CD, Hutchings L, Fairweather TP (2008) Has the fishery contributed to a major shift in the distribution of South African sardine? ICES J Mar Sci 65: 1676-1688

Cunha ME, Figueiredo I, Farinha A, Santos M (1992) Estimation of sardine spawning biomass off Portugal by the daily egg production method. Bol Inst Esp Oceanogr 8:139-153

Cury P, Bakun A, Crawford RJM, Jarre A, Quinones RA, Shannon LJ, Verheye HM (2000) Small pelagics in upwelling systems: patterns of interaction and structural changes in 'wasp-waist' ecosystems. ICES J Mar Sci 57: 603-618

Cushing DH (1989) A difference in structure between ecosystems in strongly stratified waters and in those that are only weakly stratified. J Plankton Res 11:1-13

> Dalsgaard J, St. John M, Kattner G, Müller-Navarra D, Hagen W (2003) Fatty acid trophic markers in the pelagic marine environment. Adv Mar Biol 46:225-340

Dutil JD, Lambert Y (2000) Natural mortality from poor condition in Atlantic cod (Gadus morhua). Can J Fish Aquat Sci 57:826-836

Eder EB, Lewis MN (2005) Proximate composition and energetic value of demersal and pelagic prey species from the SW Atlantic Ocean. Mar Ecol Prog Ser 291:43-52

Edwards M, Richardson AJ (2004) Impact of climate change on marine pelagic phenology and trophic mismatch. Nature 430:881-884

Figueiredo I, Santos AMP (1988) On sexual maturation, condition factor and gonosomatic index of Sardina pilchardus Walb., off Portugal (1986/1987). ICES CM 1988/H:701-27

Fiúza AFG, Macedo ME, Guerreiro MR (1982) Climatological space and time variation of the Portugal coastal upwelling. Oceanol Acta 5:31-40

Foy RJ, Paul AJ (1999) Winter feeding and changes in somatic energy content of age-0 Pacific herring in Prince William Sound, Alaska. Trans Am Fish Soc 128:1193-1200

Frank KT, Petrie B, Shackell NL, Choi JS (2006) Reconciling differences in trophic control in mid-latitude marine ecosystems. Ecol Lett 9:1096-1105

Garrido S, Marcalo A, Zwolinski J, van der Lingen CD (2007a) Laboratory investigations on the effect of prey size and concentration on the feeding behaviour of Sardina pilchardus. Mar Ecol Prog Ser 330:189-199

Garrido S, Rosa R, Ben-Hamadou R, Cunha ME, Chicharo MA, van der Lingen CD (2007b) Effect of maternal fat reserves on the fatty acid composition of sardine (Sardina pilchardus) oocytes. Comp Biochem Physiol B 148: 398-409

Garrido S, Ben-Hamadou R, Oliveira PB, Cunha ME, Chicharo MA, van der Lingen CD (2008a) Diet and feeding intensity of sardine Sardina pilchardus: correlation with satellite-derived chlorophyll data. Mar Ecol Prog Ser 354:245-256

Garrido S, Rosa R, Ben-Hamadou R, Cunha ME, Chicharo MA, van der Lingen CD (2008b) Spatio-temporal variability in fatty acid trophic biomarkers in stomach contents and muscle of Iberian sardine (Sardina pilchardus) and its relationship with spawning. Mar Biol 154:1053-1065

Hsieh CH, Reiss CS, Hunter JR, Beddington JR, May RM, Sugihara G (2006) Fishing elevates variability in the abundance of exploited species. Nature 443:859-862

Hunter JR (1981) The spawning energetics of female northern anchovy, Engraulis mordax. Fish Bull 79:215-229

Hunter JR, Leong R (1981) The spawning energetics of female northern anchovy, Engraulis mordax. Fish Bull 79: $215-230$

> Ianora A, Miralto A, Poulet SA, Carotenuto Y and others (2004) Aldehyde suppression of copepod recruitment in blooms of a ubiquitous planktonic diatom. Nature 429: 403-407

ICES (International Council for the Exploration of the Sea) (1982) Working group for the appraisal of sardine stocks in divisions VIIIC and IXa. ICES CM 1982/Assess:10:1-41

ICES (2005) Report of the working group on the assessment of mackerel, horse mackerel, sardine and anchovy. ICES CM 2005/ACFM:08:1-472

Irigoien X, Harris RP, Head RN, Harbour D (2000) North Atlantic Oscillation and spring bloom phytoplankton composition in the English Channel. J Plankton Res 22: $2367-2371$

Irigoien X, Harris RP, Verheye HM, Joly P and others (2002) Copepod hatching success in marine ecosystems with high diatom concentrations. Nature 419:387-389

Joint I, Groom SB, Wollast R, Chou L and others (2002) The response of phytoplankton production to periodic upwelling and relaxation events at the Iberian shelf break: estimates by the ${ }^{14} \mathrm{C}$ method and by satellite remote sensing. J Mar Syst 32:219-238

Jonas JL, Kraft CE, Margenau TL (1996) Assessment of seasonal changes in energy density and condition in age-0 and age-1 muskellunge. Trans Am Fish Soc 125:203-210

> Jones RH, Flynn KJ (2005) Nutritional status and diet composition affect the value of diatoms as copepod prey. Science 307:1457-1459

Kudela R, Pitcher G, Probyn T, Figueiras F, Moita T, Trainer V (2005) Harmfull algal blooms in coastal upwelling systems. Oceanography 18:184-197

> Lawson JW, Magalhães AM, Miller EH (1998) Important prey species of marine vertebrate predators in the northwest Atlantic: proximate composition and energy density. Mar Ecol Prog Ser 164:13-20

Lee RF, Hagen W, Kattner G (2006) Lipid storage in marine zooplankton. Mar Ecol Prog Ser 307:273-306

Lemos R, Pires HO (2004) The upwelling regime off the west Portuguese coast, 1941-2000. Int J Climatol 24:511-524

Lluch-Belda D, Crawford RJM, Kawasaki T, MacCall AD, Parrish RH, Schwartzlose RA, Smith PE (1989) Worldwide fluctuations of sardine and anchovy stocks: the regime problem. S Afr J Mar Sci 8:195-205

Love RM (1980) The chemical biology of fishes, Vol 2. Academic Press, New York, NY

> Madenjian CP, Elliott RF, DeSorcie TJ, Stedman RM, O'Connor DV, Rottiers DV (2000) Lipid concentrations in Lake Michigan fishes: seasonal, spatial, ontogenetic, and longterm trends. J Gt Lakes Res 26:427-444

Marques V, Morais A, Pestana G (2003) Distribuição, abundância e evolução do manancial de sardinha presente na plataforma continental Portuguesa entre 1995 e 
2002. Relatório Científicos e Técnicos IPIMAR 10:1-29 (Série digital)

Marshall CT, Yaragina NA, Lambert Y, Kjesbu OS (1999) Total lipid energy as a proxy for total egg production by fish stocks. Nature 402:288-290

Miralto A, Barone G, Romano G, Poulet SA and others (1999) The insidious effect of diatoms on copepod reproduction. Nature 402:173-176

Nagata T, Takai K, Kawabata K, Nakanishi M, Urabe J (1996) The trophic transfer via a picoplankton-flagellate-copepod food chain during a picocyanobacterial bloom in Lake Biwa. Arch Hydrobiol 137:145-160

Painting SJ, Hutchings L, Huggett JA, Korrûbel JL, Richardson AJ, Verheye HM (1998) Environmental and biological monitoring for forecasting anchovy recruitment in the southern Benguela upwelling region. Fish Oceanogr 7: 367-374

Payne SA, Johnson BA, Otto RS (1999) Proximate composition of some north-eastern Pacific forage fish species. Fish Oceanogr 8:159-177

Pedersen L, Jensen HM, Burmeister AD, Hansen BW (1999) The significance of food web structure for the condition and tracer lipid content of juvenile snail fish (Pisces: Liparis spp.) along $65-72^{\circ} \mathrm{N}$ off West Greenland. J Plankton Res 21:1593-1611

Ré P, Silva RC, Cunha E, Farinha A, Meneses I, Moita T (1990) Sardine spawning off Portugal. Bol Inst Nac Inv Pescas Lisboa 15:31-44

Relvas P, Barton ED, Dubert J, Oliveira PB, Peliz A, da Silva JCB, Santos AMP (2007) Physical oceanography of the western Iberia ecosystem: latest views and challenges. Prog Oceanogr 74:149-173

Santos AMP, Borges MDF, Groom S (2001) Sardine and horse mackerel recruitment and upwelling off Portugal. ICES J Mar Sci 58:589-596

Schülein FH, Boyd AJ, Underhill LG (1995) Oil-to-meal ratios of pelagic fish taken from the northern and the southern Benguela systems: seasonal patterns and temporal trends, 1951-1993. S Afr J Mar Sci 15:61-82

Shulman GE, Love RM (eds) (1999) The biochemical ecology of marine fishes. Adv Mar Biol 36:1-351
Shulman GE, Nikolsky VN, Yuneva TV, Minyuk GS and others (2005) Fat content in Black Sea sprat as an indicator of fish food supply and ecosystem condition. Mar Ecol Prog Ser 293:201-212

Silva A, Santos MB, Caneco B, Pestana G, Porteiro C, Carrera $\mathrm{P}$, Stratoudakis Y (2006) Temporal and geographic variability of sardine maturity at length in the northeastern Atlantic and the western Mediterranean. ICES J Mar Sci 63:663-676

St John MA, Lund T (1996) Lipid biomarkers: linking the utilization of frontal plankton biomass to enhanced condition of juvenile North Sea cod. Mar Ecol Prog Ser 131:75-85

Sutton SG, Bult TP, Haedrich RL (2000) Relationships among fat weight, body weight, water weight, and condition factors in wild Atlantic salmon parr. Trans Am Fish Soc 129: $527-538$

Tierney M, Hindell M, Goldsworthy S (2002) Energy content of mesopelagic fish from Macquarie Island. Antarct Sci 14: $225-230$

Trudel M, Tucker S, Morris JFT, Higgs DA, Welch DW (2005) Indicators of energetic status in juvenile coho salmon and Chinook salmon. N Am J Fish Manag 25:374-390

Van Pelt TI, Piatt JF, Lance BK, Roby DD (1997) Proximate composition and energy density of some North Pacific forage fishes. Comp Biochem Physiol A 118:1393-1398

Ware DM, Thomson RE (2005) Bottom-up ecosystem trophic dynamics determine fish production in the northeast. Pac Sci 308:1280-1284

Winberg GC (1971) Methods for estimation of production of aquatic animals. Academic Press, New York, NY

> Woodruff SD, Diaz HF, Elms JD, Worley SJ (1998) COADS Release 2-data and metadata enhancements for improvements of marine surface flux fields. Phys Chem Earth 23:517-527

Worm B, Myers RA (2003) Meta-analysis of cod-shrimp interactions reveals top-down control in oceanic food webs. Ecology 84:162-173

Zwolinski J, Stratoudakis Y, Soares E (2001) Intra-annual variation in the batch fecundity of sardine off Portugal. J Fish Biol 58:1633-1645

Appendix. Relationships between sardine energy density and individual environmental variables (sea surface temperature and offshore Ekman transport) with full data set (Table A1) and restricted to end of feeding season (Table A2)

Table A1. Sardina pilchardus. Relationships between seasonally adjusted energy density (rED; full data set) and the seasonally adjusted series of sea-surface temperature (SST) and offshore Ekman transport $\left(Q_{\mathrm{x}}\right)$. Akaike information criteria (AIC) are given. Restricted maximum-likelihood was used to estimate the parameters of each of the models (with and without taking autocorrelation into account). Statistical significance at the ${ }^{*} 5 \%,{ }^{* *} 1 \%$ level of significance; AR(1): first-order autogressive models; SE: standard error, in parentheses

\begin{tabular}{|c|c|c|c|c|c|c|c|c|c|c|}
\hline \multirow{2}{*}{$\begin{array}{l}\text { Explanatory } \\
\text { variable }\end{array}$} & \multicolumn{5}{|c|}{ Without autocorrelation } & \multicolumn{5}{|c|}{-With autocorrelation } \\
\hline & Coefficient (SE) & $t$ & $\mathrm{p}$ & Total $\mathrm{R}^{2}(\%)$ & $\mathrm{AIC}$ & Coefficient (SE) & $t$ & $\mathrm{p}$ & Total $\mathrm{R}^{2}(\%)$ & $\mathrm{AIC}$ \\
\hline \multicolumn{11}{|c|}{ Sea-surface temperature } \\
\hline $\begin{array}{l}\text { SST } \\
\operatorname{AR}(1)\end{array}$ & $0.16(0.17)$ & 0.99 & 0.3242 & 0.80 & 365.64 & $\begin{array}{l}0.25(0.15) \\
0.57(0.08)\end{array}$ & $\begin{array}{l}1.64 \\
7.63^{* *}\end{array}$ & $\begin{array}{r}0.1031 \\
<0.0001\end{array}$ & 34.24 & 318.47 \\
\hline $\begin{array}{l}\text { Lag } 1 \text { (SST) } \\
\text { AR(1) }\end{array}$ & $-0.20(0.17)$ & -1.20 & 0.2320 & 1.17 & 365.17 & $\begin{array}{r}-0.21(0.16) \\
0.56(0.08)\end{array}$ & $\begin{array}{l}-1.30 \\
7.35^{* *}\end{array}$ & $\begin{array}{r}0.1951 \\
<0.0001\end{array}$ & 33.70 & 319.42 \\
\hline $\begin{array}{l}\text { Lag } 2 \text { (SST) } \\
\text { AR(1) }\end{array}$ & $-0.38(0.16)$ & $-2.32^{*}$ & 0.0222 & 4.25 & 358.97 & $\begin{array}{r}-0.14(0.16) \\
0.55(0.08)\end{array}$ & $\begin{array}{l}-0.89 \\
7.16^{* *}\end{array}$ & $\begin{array}{r}0.3771 \\
<0.0001\end{array}$ & 33.13 & 318.48 \\
\hline $\begin{array}{l}\text { Lag } 3 \text { (SST) } \\
\text { AR(1) }\end{array}$ & $-0.53(0.16)$ & $-3.33^{* *}$ & 0.0011 & 8.47 & 351.54 & $\begin{array}{r}-0.30(0.17) \\
0.53(0.08)\end{array}$ & $\begin{array}{l}-1.78 \\
6.78^{* *}\end{array}$ & $\begin{array}{r}0.0783 \\
<0.0001\end{array}$ & 34.31 & 314.63 \\
\hline
\end{tabular}


Table A1 (continued)

\begin{tabular}{|c|c|c|c|c|c|c|c|c|c|c|}
\hline \multirow{2}{*}{$\begin{array}{l}\text { Explanatory } \\
\text { variable }\end{array}$} & \multicolumn{5}{|c|}{ Without autocorrelation- } & \multicolumn{5}{|c|}{ With autocorrelation } \\
\hline & Coefficient (SE) & $t$ & $\mathrm{p}$ & Total $\mathrm{R}^{2}(\%)$ & $\mathrm{AIC}$ & Coefficient (SE) & $t$ & $\mathrm{p}$ & Total $\mathrm{R}^{2}(\%)$ & $\mathrm{AIC}$ \\
\hline \multicolumn{11}{|c|}{ Ekman transport $\left(Q_{\mathrm{x}}\right)$} \\
\hline $\begin{array}{l}Q_{\mathrm{x}} \\
\operatorname{AR}(1)\end{array}$ & $0.00(0.00)$ & -0.23 & 0.8207 & 0.04 & 366.58 & $\begin{array}{l}0.00(0.00) \\
0.56(0.08)\end{array}$ & $\begin{array}{r}-0.13 \\
7.45^{* *}\end{array}$ & $\begin{array}{r}0.8977 \\
<0.0001\end{array}$ & 32.75 & 321.19 \\
\hline $\begin{array}{l}\operatorname{Lag} 1\left(Q_{\mathrm{x}}\right) \\
\operatorname{AR}(1)\end{array}$ & $0.00(0.00)$ & -0.12 & 0.9057 & 0.01 & 366.62 & $\begin{array}{l}0.00(0.00) \\
0.57(0.08)\end{array}$ & $\begin{array}{l}-0.91 \\
7.56^{* *}\end{array}$ & $\begin{array}{r}0.3642 \\
<0.0001\end{array}$ & 33.21 & 320.36 \\
\hline $\begin{array}{l}\operatorname{Lag} 2\left(Q_{\mathrm{x}}\right) \\
\operatorname{AR}(1)\end{array}$ & $0.00(0.00)$ & 1.46 & 0.1459 & 1.74 & 362.15 & $\begin{array}{l}0.00(0.00) \\
0.56(0.08)\end{array}$ & $\begin{array}{l}0.28 \\
7.33^{* *}\end{array}$ & $\begin{array}{r}0.7779 \\
<0.0001\end{array}$ & 32.78 & 319.18 \\
\hline $\begin{array}{l}\operatorname{Lag} 3\left(Q_{\mathrm{x}}\right) \\
\operatorname{AR}(1)\end{array}$ & $0.00(0.00)$ & $3.26^{* *}$ & 0.0015 & 8.12 & 352.01 & $\begin{array}{l}0.00(0.00) \\
0.54(0.08)\end{array}$ & $\begin{array}{l}2.12^{*} \\
7.04^{* *}\end{array}$ & $\begin{array}{r}0.0363 \\
<0.0001\end{array}$ & 35.09 & 313.23 \\
\hline
\end{tabular}

Table A2. Sardina pilchardus. Relationships between seasonally adjusted energy density (rED) at the end of the main feeding period of European sardines (between August and October) and the seasonally adjusted series of sea-surface temperature (SST) and offshore Ekman transport $\left(Q_{\mathrm{x}}\right)$. Akaike information criteria (AIC) are given. Restricted maximum-likelihood was used to estimate the parameters (with and without taking autocorrelation into account). Statistical significance at the *5\% level of significance; ${ }^{* *} 1 \%$ level of significance; AR(1): first-order autogressive models; SE: standard error, in parentheses

\begin{tabular}{|c|c|c|c|c|c|c|c|c|c|c|}
\hline \multirow{2}{*}{$\begin{array}{l}\text { Explanatory } \\
\text { variable }\end{array}$} & \multicolumn{5}{|c|}{ Without autocorrelation } & \multicolumn{5}{|c|}{ - With autocorrelation- } \\
\hline & Coefficient (SE) & $t$ & $\mathrm{p}$ & Total $\mathrm{R}^{2}(\%)$ & $\mathrm{AIC}$ & Coefficient (SE) & $t$ & $\mathrm{p}$ & Total $\mathrm{R}^{2}(\%)$ & $\mathrm{AIC}$ \\
\hline \multicolumn{11}{|c|}{ Sea-surface temperature } \\
\hline $\begin{array}{l}\text { SST } \\
\text { AR(1) }\end{array}$ & $0.26(0.36)$ & 0.70 & 0.4880 & 1.56 & 121.49 & $\begin{array}{l}0.07(0.24) \\
0.75(0.10)\end{array}$ & $\begin{array}{l}0.29 \\
7.53^{* *}\end{array}$ & $\begin{array}{r}0.7743 \\
<0.0001\end{array}$ & 56.60 & 105.64 \\
\hline $\begin{array}{l}\text { Lag } 1 \text { (SST) } \\
\text { AR(1) }\end{array}$ & $-0.27(0.40)$ & -0.68 & 0.4998 & 1.48 & 121.52 & $\begin{array}{r}-0.23(0.28) \\
0.76(0.10)\end{array}$ & $\begin{array}{l}-0.81 \\
7.64^{* *}\end{array}$ & $\begin{array}{r}0.4241 \\
<0.0001\end{array}$ & 57.67 & 105.02 \\
\hline $\begin{array}{l}\text { Lag } 2(\mathrm{SST}) \\
\mathrm{AR}(1)\end{array}$ & $-0.76(0.43)$ & -1.77 & 0.0859 & 9.22 & 118.82 & $\begin{array}{r}-0.65(0.41) \\
0.76(0.10)\end{array}$ & $\begin{array}{l}-1.60 \\
7.81^{* *}\end{array}$ & $\begin{array}{r}0.1201 \\
<0.0001\end{array}$ & 60.35 & 103.03 \\
\hline $\begin{array}{l}\text { Lag } 3 \text { (SST) } \\
\text { AR(1) }\end{array}$ & $-0.99(0.42)$ & $-2.34^{*}$ & 0.0258 & 15.04 & 116.64 & $\begin{array}{r}-0.41(0.46) \\
0.73(0.11)\end{array}$ & $\begin{array}{l}-0.89 \\
6.66^{* *}\end{array}$ & $\begin{array}{r}0.3811 \\
<0.0001\end{array}$ & 56.33 & 104.92 \\
\hline \multicolumn{11}{|c|}{ Ekman transport $\left(Q_{\mathrm{x}}\right)$} \\
\hline $\begin{array}{l}Q_{\mathrm{x}} \\
\operatorname{AR}(1)\end{array}$ & $0.00(0.00)$ & 0.33 & 0.7459 & 0.34 & 121.90 & $\begin{array}{l}0.00(0.00) \\
0.76(0.10)\end{array}$ & $\begin{array}{l}0.56 \\
7.98^{* *}\end{array}$ & $\begin{array}{r}0.5786 \\
<0.0001\end{array}$ & 57.44 & 105.40 \\
\hline $\begin{array}{l}\operatorname{Lag} 1\left(Q_{\mathrm{x}}\right) \\
\operatorname{AR}(1)\end{array}$ & $0.00(0.00)$ & -0.33 & 0.7422 & 0.35 & 121.90 & $\begin{array}{l}0.00(0.00) \\
0.76(0.10)\end{array}$ & $\begin{array}{l}-0.78 \\
7.82^{* *}\end{array}$ & $\begin{array}{r}0.4409 \\
<0.0001\end{array}$ & 57.89 & 105.08 \\
\hline $\begin{array}{l}\operatorname{Lag} 2\left(Q_{\mathrm{x}}\right) \\
\operatorname{AR}(1)\end{array}$ & $0.00(0.00)$ & $2.25^{*}$ & 0.0315 & 14.07 & 117.01 & $\begin{array}{l}0.00(0.00) \\
0.75(0.10)\end{array}$ & $\begin{array}{l}2.48^{*} \\
7.14^{* *}\end{array}$ & $\begin{array}{r}0.0188 \\
<0.0001\end{array}$ & 63.74 & 99.52 \\
\hline $\begin{array}{l}\operatorname{Lag} 3\left(Q_{\mathrm{x}}\right) \\
\operatorname{AR}(1)\end{array}$ & $0.00(0.00)$ & $3.57^{* *}$ & 0.0012 & 29.08 & 110.68 & $\begin{array}{l}0.00(0.00) \\
0.71(0.12)\end{array}$ & $\begin{array}{l}2.14^{*} \\
5.95^{* *}\end{array}$ & $\begin{array}{r}0.0410 \\
<0.0001\end{array}$ & 60.20 & 101.21 \\
\hline
\end{tabular}

Editorial responsibility: Konstantinos Stergiou, Thessaloniki, Greece
Submitted: September 21, 2009; Accepted: April 21, 2010 Proofs received from author(s): June 25, 2010 